\title{
Crohn's disease defined in three elderly sisters
}

\author{
Hugh J Freeman MD
}

HJ Freeman. Crohn's disease defined in three elderly sisters. Can J Gastroenterol 2005;19(4):251-252.

\begin{abstract}
Three elderly sisters presented with symptomatic Crohn's disease. All had ileocolic involvement, and granulomatous inflammation was documented in endoscopic biopsies or surgically resected intestinal specimens. The present report documents the unusual occurrence of very late phenotypical expression of familial ileocolic Crohn's disease. The observations presented here reflect a possible gene-based predisposition to Crohn's disease or, alternatively, disease clustering related to a commonly shared environmental factor.
\end{abstract}

Key Words: Crohn's disease; Crohn's disease in the elderly; Familial Crohn's disease; Phenotypical expression of Crohn's disease

\section{Une maladie de Crohn définie chez trois sœurs âgées}

Trois sœurs âgées ont consulté parce qu'elles souffraient d'une maladie de Crohn symptomatique. Toutes trois présentaient une atteinte iléocolique, et une inflammation granulomateuse a été documentée par biopsie endoscopique ou dans des échantillons intestinaux réséqués par voie chirurgicale. Le présent article documente l'occurrence inhabituelle de l'expression phénotypique très tardive d'une maladie de Crohn iléocolique familiale. Les observations présentées reflètent la possibilité d'une prédisposition génétique à la maladie de Crohn ou d'une concentration de la maladie reliée à un même facteur environnemental.
$\mathrm{P}$ rior studies, largely from European and American centres, have recorded familial occurrences of Crohn's disease, and have led to the conclusion that the single strongest factor influencing the appearance of this disease is having an affected relative (1). It is popularly hypothesized that genetic susceptibility coupled with environmental factors such as infectious agents may result in disease expression (2). Reports describing the detection of disease-related NOD2 alleles that predispose some individuals to Crohn's disease have also recently generated even more enthusiasm for the role of genetic factors $(3,4)$.

Studies from Canada on familial Crohn's disease have been limited to case reports $(5,6)$, a retrospective survey $(7)$ and data from an ethnic group (8). Additionally, an earlier investigation (9) based on a prospectively defined clinical database of over 1000 patients and limited to first-degree relatives, showed that $8.7 \%$ of Crohn's disease patients have either single or multiple first-degree affected relatives. Moreover, siblings, particularly females, were most commonly affected. The present report documents a particularly unusual occurrence of three sisters with late phenotypical expression of ileocolic Crohn's disease.

\section{CASE PRESENTATIONS}

\section{Case 1}

A 70-year-old woman suffering from abdominal pain and diarrhea was first evaluated in 1979 after transfer from a local nursing home. She had chronic schizophrenia, which was treated with antipsychotic medication. A diagnosis of Crohn's disease involving the ileum and the cecum was established by barium studies. She developed a skin rash with sulfasalazine treatment. Symptoms persisted despite alternate-day prednisone; as a result, an ileocolic resection was performed along with a cholecystectomy for gallstones. In July 1980, she was readmitted for recurrent abdominal pain, diarrhea and perianal pain. She refused to provide any further details related to her personal clinical illness or any familial history. Her abdomen was tender in the left lower quadrant, and speculum examination showed a rectovaginal fistula. Sigmoidoscopy showed an area of focal ulceration on the anterior rectal wall $4 \mathrm{~cm}$ from the anal verge, and biopsies showed focal rectal granulomatous inflammation. A sigmoid colostomy was performed. At the time of laparotomy, extensive colonic involvement with Crohn's disease was evident. In January 1981, she was discharged to a long-term care facility on $500 \mathrm{mg}$ sulfasalazine four times daily and $7.5 \mathrm{mg}$ prednisone daily. Her subsequent clinical course was complicated by osteopenic bone disease, fractures of the humerus and hip (the latter requiring open reduction for an intratrochanteric fracture), congestive heart failure and marked proteinuria (thought to be due to renal amyloidosis). In 1996, she died at 87 years of age.

\section{Case 2}

An 80-year-old woman was first seen for constipation in September 1989. She first reported two sisters with Crohn's disease (cases 1 and 3 in the present report). She was anemic (hemoglobin $103 \mathrm{~g} / \mathrm{L}$ ) and hypoalbuminemic (serum albumin $32 \mathrm{~g} / \mathrm{L}$ ), with an elevated sedimentation rate of $60 \mathrm{~mm} / \mathrm{h}$. Occult blood tests were positive, and barium studies of her

Department of Medicine, Division of Gastroenterology, University of British Columbia, Vancouver, British Columbia

Correspondence: Dr Hugh Freeman, Gastroenterology, University of British Columbia Hospital, 2211 Wesbrook Mall, Vancouver,

British Columbia V6T 1W5. Telephone 604-822-7216, fax 604-822-7236, e-mail hugfree@shaw.ca

Received for publication November 8, 2004. Accepted March 2, 2005 
upper and lower intestinal tracts showed stenosis and ulceration of the terminal ileum. Colonoscopy appeared normal, and biopsies of her colon showed patchy and nonspecific inflammatory changes with no dysplasia. An ileal mucosal biopsy showed granulomatous inflammation. Recurrent bouts of intestinal obstruction occurred over the next five years. These episodes responded to symptomatic management with nasogastric suction and intravenous fluids alone. In 1993, upper endoscopy and biopsies of the stomach and duodenum were normal. In 1995, due to persistent anemia, flexible sigmoidoscopy with biopsies were repeated and normal; however, a barium enema showed a persistent terminal ileal stricture and some minimal colonic mucosal inflammatory changes. In May 1997, she suffered a severe cerebrovascular accident with subsequent development of progressive dementia. She was transferred to a long-term care facility and died in 2001 at 92 years of age.

\section{Case 3}

A 79-year-old woman was first reported by the patient in case 2 to have Crohn's disease of the small and large bowel as early as 1989. Subsequent historical enquiry revealed that she had undergone an extended ileocolic resection for ileocolic involvement with Crohn's disease in another teaching hospital after presentation with symptoms of a bowel obstruction. Granulomatous inflammation was confirmed in the resected specimen. Postoperatively, she did well and suffered no significant complications related to her Crohn's disease, but died 13 years later in 1991 from progressive renal failure.

Further family history revealed that there were two other sisters who had no known inflammatory bowel disease. Both are now deceased. No other family members from previous or subsequent generations were known to develop inflammatory bowel disease. All five sisters were urban dwellers and there was no known record of consumption of unpasteurized milk products. A single affected sister (case 3 ) married and had a

\section{REFERENCES}

1. Sachar DB. Crohn's disease: A family affair. Gastroenterology 1996;11:813-5.

2. Todd JA. Human genetics. Tackling common disease. Nature 2001;411:537-8.

3. Hugot JP, Chamaillard M, Zouali H, et al. Assocation of NOD2 leucine-rich repeat variants with susceptibility to Crohn's disease. Nature 2001;411:599-603

4. Ogura Y, Bonen DK, Inohara N, et al. A frameshift mutation in NOD2 associated with susceptibility to Crohn's disease. Nature 2001;411:603-6.

5. Hershfield NB. Crohn's disease in a mother, father and son. Can Med Assoc J 1984;131:1190, 1193.

6. Murray CJ, Thomson AB. Marital idiopathic inflammatory bowel disease. Crohn's disease in a husband and wife. J Clin Gastroenterol 1988;10:95-7.

7. McLeod RS, Steinhart AH, Siminovitch KA, et al. Preliminary report on the Mount Sinai Hospital Inflammatory Bowel Disease Genetics Project. Dis Colon Rectum 1997;40:553-7.

8. Freeman HJ. Inflammatory bowel diseases in Indo-Canadians with and without antineutrophil cytoplasmic autoantibodies. Can J Gastroenterol 2000;14:21-6.

9. Freeman HJ. Familial Crohn's Disease in single or multiple firstdegree relatives. J Clin Gastroenterol 2002;35:9-13. son. This man and his father have no gastrointestinal or other autoimmune disorder at the time of writing.

\section{DISCUSSION}

Earlier Canadian studies have estimated that Crohn's disease occurs in approximately $8 \%$ to $10 \%$ of patient relatives $(7,9)$. The period of follow-up in such studies, however, is critical because additional first-degree relatives may be added over time, including children and late-diagnosed adults (10). The present report of three elderly sisters with Crohn's disease further emphasizes this important confounding issue in familial studies due to the potential for the very late phenotypical expression of the disorder. Although over $80 \%$ of patients with Crohn's disease are diagnosed before the age of 40 years, in our experience the initial diagnosis may be first established in elderly patients (11). Indeed, the initial diagnosis of Crohn's disease has been reported by others elsewhere, even in a 92-year-old man (12).

While familial Crohn's disease may have a significant genetic basis, it is very important to consider the critically potential role of "disease clustering". Intermarriage among Jews or Indo-Canadians may be an important factor $(8,13,14)$. In addition, clustering has been described in the Nord-Pas de Calais region of France and Belgium $(15,16)$, and Mankato, Minnesota (17). College clustering has also been described (18) along with genetically unrelated spousal pairs (or clusters) (6). Even among first-degree relatives, as in the present report, exposure for variable periods of time to a genetically related person with Crohn's disease may represent an environmental rather than an inherited risk factor for developing the disease, even as documented here in these three sisters with unusually late phenotypical expression. Further studies are clearly needed to define with greater certainty the role of genetic and environmental factors in the etiopathogenesis of Crohn's disease.

10. Freeman HJ, Hershfield NB. Anticipation in an Indo-Canadian family with Crohn's disease. Can J Gastroenterol 2001;15:695-8

11. Freeman HJ. Application of the Vienna Classification for Crohn's disease to a single clinician database of 877 patients. Can J Gastroenterol 2001;15:89-93.

12. Narita T, Akiyama M, Ohnuma H, Matsuda K. Crohn's disease in a 92-year-old male. J Gastroenterol 1996;31:114-8.

13. Weterman IT, Pena AS. Familial incidence of Crohn's disease in The Netherlands and a review of the literature. Gastroenterology 1984;86:449-52.

14. Yang H, McElree C, Roth MP, Shanahan F, Targan SR, Rotter JI. Familial empirical risks for inflammatory bowel disease: Differences between Jews and non-Jews. Gut 1993;34:517-24

15. van Kruiningen HJ, Colombel JF, Cartun RW, et al. An in-depth study of Crohn's disease in two French families. Gastroenterology 1993;104:351-60

16. van Kruiningen HJ, Cortot A, Colombel JF, et al. The importance of familial clusterings in Crohn's disease. Inflamm Bowel Dis 2001;7:170-3.

17. van Kruiningen HJ, Freda BJ. A clustering of Crohn's disease in Mankato, Minnesota. Inflamm Bowel Dis 2001;7:27-33.

18. Aisenberg J, Janowitz HD. Cluster of inflammatory bowel disease in three close college friends. J Clin Gastroenterol 1993;17:18-20. 


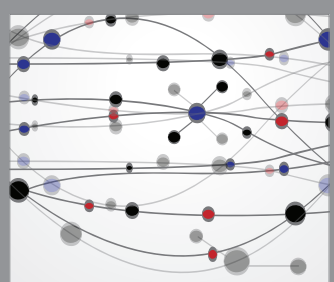

The Scientific World Journal
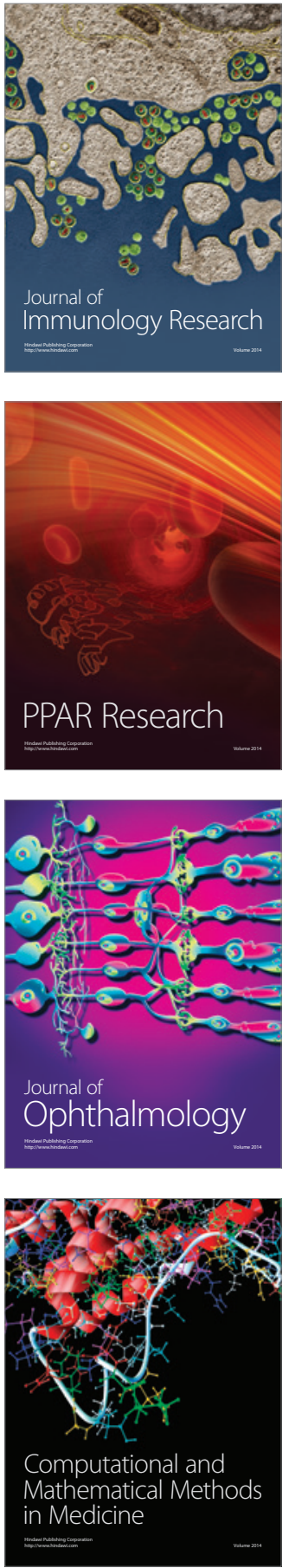

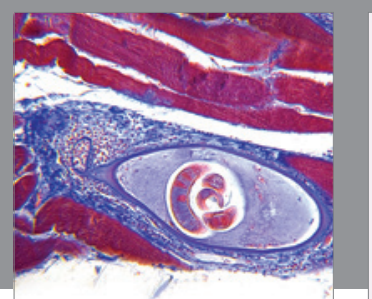

Gastroenterology Research and Practice

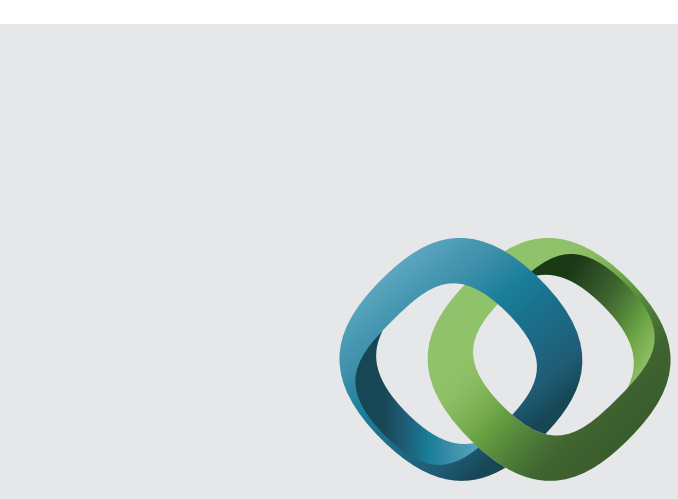

\section{Hindawi}

Submit your manuscripts at

http://www.hindawi.com
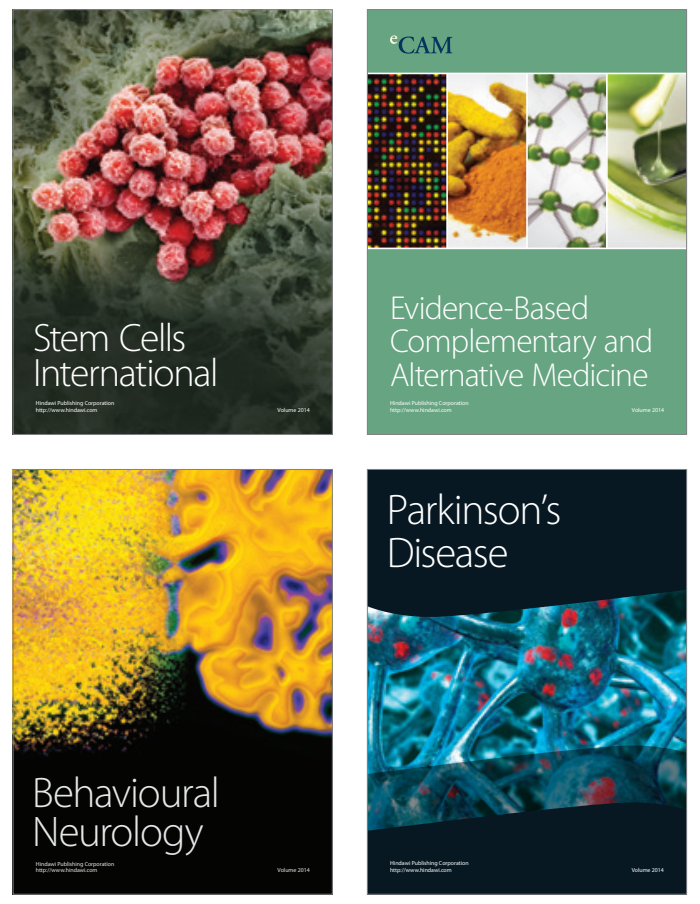
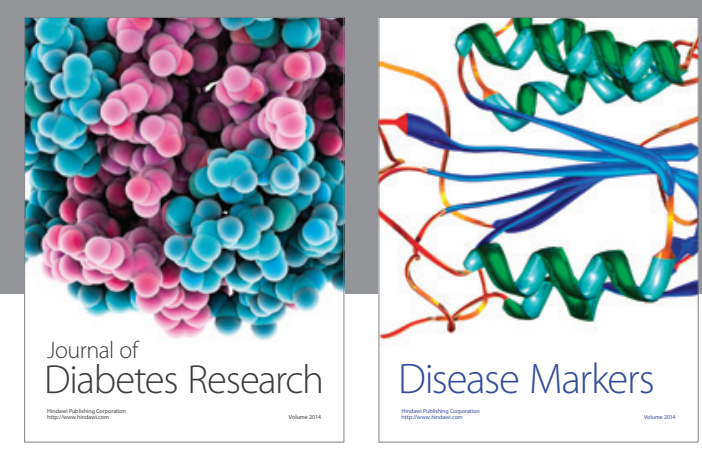

Disease Markers
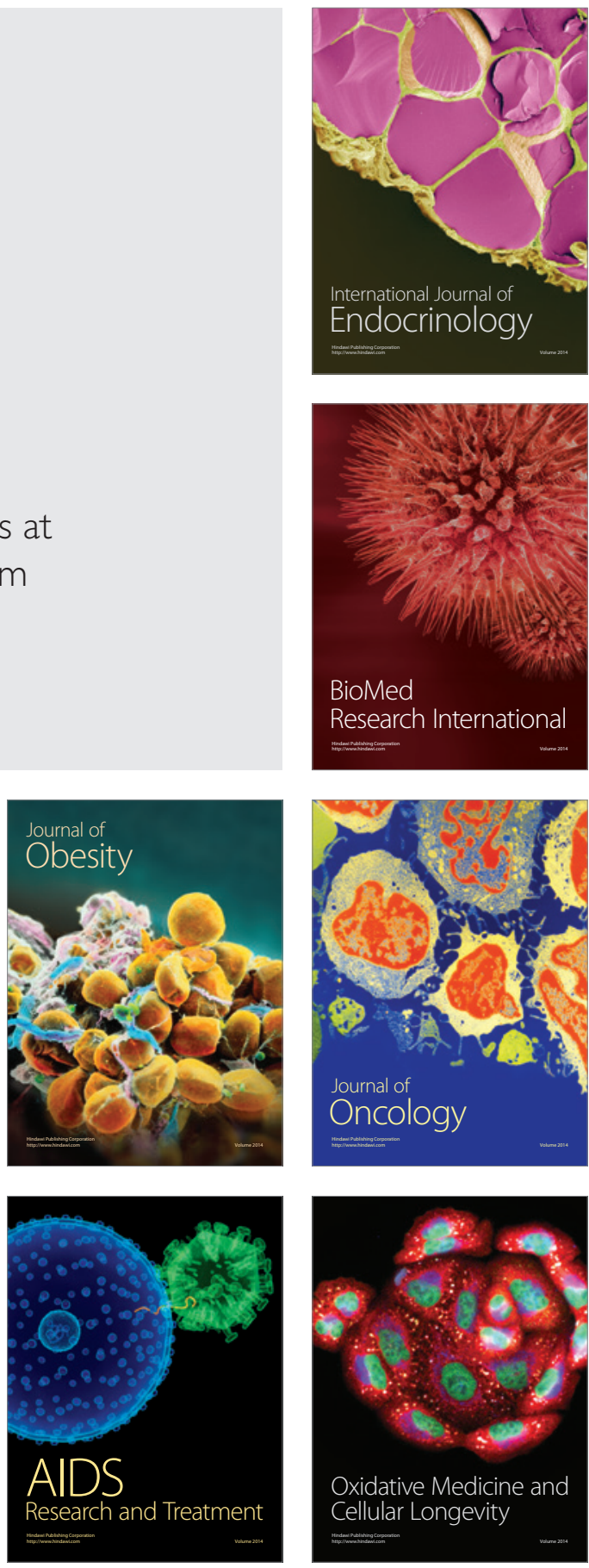